Article

\title{
Using an Environment-Friendly Fertiliser from Sewage Sludge Ash with the Addition of Bacillus megaterium
}

\author{
Magdalena Jastrzębska *(1) and Marta K. Kostrzewska \\ Department of Agroecosystems, Faculty of Environmental Management and Agriculture, University of Warmia \\ and Mazury in Olsztyn, Plac Łódzki 3, 10-718 Olsztyn, Poland \\ * Correspondence: jama@uwm.edu.pl
}

Received: 15 May 2019; Accepted: 9 July 2019; Published: 11 July 2019

check for updates

\begin{abstract}
Sewage sludge ash (SSA) is considered to be a valuable secondary raw material for the production of phosphorous fertilisers. This method of recycling may also be a solution to the problem posed by the growing amount of this waste. An innovative suspension fertiliser (SSAB) was produced from SSA and the phosphorus-solubilising bacteria Bacillus megaterium and was tested in a field experiment in the presence of spring wheat as the test plant in comparison to conventional fertilisers (superphosphate, phosphorite). Two variants of plant protection were also adopted: full chemical plant protection (+PP) and no plant protection (-PP). Besides affecting yield, it was expected that SSAB would not worsen the state of the soil environment. This paper presents SSAB effect on soil moisture and temperature, soil $\mathrm{pH}$, content of toxic elements (As, $\mathrm{Cd}, \mathrm{Cr}, \mathrm{Ni}$ and $\mathrm{Pb}$ ) in the soil, abundance of heterotrophic bacteria and fungi and the occurrence of earthworms. SSAB did not affect the tested soil characteristics when applied in reasonable doses. Plant protection had an individual effect on soil properties but did not modify the fertiliser action. SSAB may be a potential substitute for $\mathrm{P}$ fertilisers produced from non-renewable raw materials in times of shortage. Further long-term research is recommended to confirm these findings.
\end{abstract}

Keywords: recycled fertiliser; soil environment; heavy metals; field experiment; plant protection; Triticum aestivum $\mathrm{L}$.

\section{Introduction}

Although the application of phosphorus (P) fertilisers is accompanied by a number of negative environmental effects [1], modern agricultural production cannot do without them, and it is hard to imagine that this dependence will change if we take into account the biological importance of phosphorus [2] and the need to meet the food needs of the fast-growing world human population [3]. Mogollón et al. [4] forecast that the global P input by fertilisers in croplands will increase from 14.5 million tonnes per year in 2005 to 22-27 million tonnes per year in 2050, and 4-12 million tonnes per year would be needed in 2050 for global intensively managed grasslands to maintain fertility.

The issues of P scarcity, its squandering and environmental pollution with $\mathrm{P}$ compounds call for a sustainable, circular economy of this element, which is based on the prudent use of mined resources, limited $\mathrm{P}$ accumulation in agricultural soils and enhanced $\mathrm{P}$ use efficiency and recycling [5].

There have been attempts to replace non-renewable phosphate rocks with P-rich secondary raw materials [6]. The attention of scientists and technologists has been focused on sewage sludge ash (SSA). The P content in dry matter of SSA ranges from less than $10 \%$ to less than $20 \%$ [7], which is comparable to the content of this element in commercial phosphate rock $(10.9-16.13 \% \mathrm{P})$ as reported by the International Fertiliser Development Centre [8]. According to recent estimates, the annual 
global production of SSA is about 1.7 million tonnes and is expected to increase in the future [9]. As the treatment of wastewater and management of process by-products are now another major global issue [10], the use of SSA as a fertiliser may also alleviate this dilemma. Some EU countries have already introduced or intend to introduce a mandatory legal obligation to recover $\mathrm{P}$ from sewage sludge and slaughterhouse waste [11].

The direct application of SSA into the soil would be the simplest and cheapest recycling method, but the raw material may contain significant amounts of toxic elements [12]. European Directive 87/278/CEE establishes limit values for the concentration and annual load for specific elements, which are often exceeded in SSA. Moreover, some countries have even stricter limits which hinder the reuse of SSA without pre-treatment [12]. It should also be noted that P contained in SSA is not plant-available due to its strong bonds in ash minerals [13].

In numerous scientific centres, research on the use of SSA as a raw material for fertiliser production has been carried out $[7,14-17]$. Many products were tested for their agronomic utility, but primarily plant availability and crop-enhancing efficiency were evaluated, mainly in pot experiments [18]. Although the results appear promising $[14,17,19]$, some weak points of SSA-based fertilisers, e.g., low solubility of P compounds, were also reported [16,18].

The inclusion of phosphorus-solubilising microbes (PSM) into SSA-based fertilisers is an innovative approach, initiated to activate $P$ from raw material [20]. Bacillus megaterium has been found to be one of the most effective PSM [21]. Generally, this strain is a component of soil edaphon but it is characterised by high ecological plasticity and has been found in different environments [22]. The biology of B. megaterium is quite well known. P solubilisation by these bacteria is performed thanks to the production of weak organic acids [23]. Through solubilisation and other biological mechanisms, PSM can also work as a plant growth-promoting microorganism (PGPM) [24]. PSM, including B. megaterium, were already used to increase the efficiency of $P$ fertilisers from primary raw materials [25] and they had been applied independently to mobilise soil $P$ reserves [26]. It could be expected that PSM introduced into soil along with fertiliser would also be involved in soil P solubilisation, which would allow to reduce the fertiliser dose. It is worth recalling that in some industrialised countries, soil $\mathrm{P}$ reserves (resulting from intensive $P$ fertilisation in the 1970s and 1980s) may be substantial [27]. One requirement for their use is to transform them into bioavailable forms [4]. However, since the use of PSM and PGPM in agriculture as environmental-friendly tools to increase crop yield is becoming increasingly common, the issue of 'non-target' effects of these organisms on native soil microbial communities is gaining prominence. To date, this matter has been rarely studied [28].

Whether recycling fertilisers, including the PSM-activated ones, will be able to replace or supplement traditional fertilisers will be determined not only by their effectiveness in providing satisfactory yields in terms of quantity and quality but also by the lack of significant changes in the soil environment following their use. With regard to the latter, there is little research, especially under field conditions.

A research consortium from Poland has collaborated on P fertiliser production technology using cheap renewable raw materials and PSM [20]. One proposal is a suspension preparation from SSA with the addition of B. megaterium bacteria (SSAB). Its performance was tested in field trials in comparison to traditional P-fertilisers. The results were compared to full chemical plant protection (+PP) and no plant protection (-PP). It was shown elsewhere [29] that SSAB was not inferior to the commercial fertilisers in terms of its effect on wheat yield volumes, the uptake of $\mathrm{P}$ by wheat and the sanitary condition of wheat fields, especially when they were grown-protected from weeds, pathogens and pests.

This paper focuses on the assessment of SSAB effect on selected soil environment properties with a test plant, i.e., soil moisture and temperature, soil $\mathrm{pH}$, content of toxic elements (As, $\mathrm{Cd}, \mathrm{Cr}$, $\mathrm{Ni}$ and $\mathrm{Pb}$ ) in the soil, abundance of heterotrophic bacteria and fungi and occurrence of earthworms (Lumbricidae). The research was based on the following assumptions: (i) soil moisture, temperature and $\mathrm{pH}$, as well as the abundance and availability of $\mathrm{P}$, have a direct bearing on the level of microbial activity in the soil [30] and on the activity of B. megaterium introduced with SSAB, (ii) the form of $\mathrm{P}$ 
fertiliser added to the soil can affect soil acidity, principally through the release or gain of $\mathrm{H}^{+}$ions by the phosphate molecule depending on soil $\mathrm{pH}$ [31] and because, under $\mathrm{P}$ stress conditions, the plants can change the $\mathrm{pH}$ of the substrate through the release of organic acids which dissolve the poorly soluble phosphates [32], (iii) the potential presence of heavy metals and other toxic elements in SSAB may increase their accumulation in soil [33], (iv) the introduction of B. megaterium, as an ingredient of SSAB, to the soil environment could modify soil biology due to an increase in the strain population size followed by the reorganisation of the microbial community structure [34] and the modification of the chemical parameters of the soil environment (acid production) [30], (v) the intensity of microbiological processes [35] and the possible stimulation of crop growth resulting from the application of SSAB could indirectly lead to changes in soil moisture and temperature, (vi) changes in habitat parameters could affect the abundance of earthworms which are soil health bioindicators [36].

It was hypothesised that SSAB would not deteriorate the properties of the soil environment, i.e., that its impact would be similar or more favourable than that of traditional P-fertilisers and that plant protection would not modify SSAB effect on the analysed parameters.

\section{Materials and Methods}

\subsection{Experimental Design and Agronomic Management}

A field experiment was conducted in 2015 in Bałcyny (Poland, $53.60^{\circ} \mathrm{N}, 19.85^{\circ} \mathrm{E}$ ). The test plant was a spring cultivar of common wheat (Triticum aestivum ssp. vulgare Mac Key, cv. Monsun). In the experiment, SSAB was confronted with two commercial fertilisers: superphosphate (SP) and phosphorite (PR). Ten variants of P fertilisation were compared (Table 1).

Table 1. P fertilisation treatments tested in the experiment and fertiliser characteristics.

\begin{tabular}{cccc}
\hline P fertiliser & Treatment Symbol & P dose (kg/ha) & Fertiliser Characteristics (Elemental Composition of \\
Fertilisers)
\end{tabular}

LD: detection level, SSA: sewage sludge ash.

SP (Gdańsk Phosphate Fertilisers Plant 'Fosfory', Gdańsk, Poland) was purchased on the market. PR (bought at the Luvena, Luboń, Poland) was supplied by the Institute of New Chemical Synthesis in Puławy. SSAB was manufactured at the Institute of New Chemical Syntheses in Puławy (Poland), according to a concept developed at the Wrocław University of Science and Technology (Poland). SSA for the SSAB production was obtained from the Łyna Municipal Wastewater Treatment Plant in Olsztyn (Poland). The B. megaterium strain was obtained from the Polish Collection of Microorganisms at the Institute of Immunology and Experimental Therapy of the Polish Academy of Sciences in Wrocław (Poland). The SSAB production process consisted of the following steps: comminution of the raw material, preparation of the culture medium for B. megaterium (mixing particular components, high-temperature sterilising, cooling down the solution to $35^{\circ} \mathrm{C}$ ), inoculation of the solution with B. megaterium, solubilisation for 7-10 days (incubation at $35{ }^{\circ} \mathrm{C}$ with mixing), stabilisation of the 
suspension with bentonite. The content of the culture medium for B. megaterium and the details of the SSAB production procedure were described by Rolewicz et al. [37].

Moreover, in the experiment, two variants of plant protection were adopted: no protection (-PP) and full protection $(+\mathrm{PP})$.

The experiment was set up in a parallel strip design with four replications (Figure S1). The size of a single experimental plot was $20 \mathrm{~m}^{2}(2 \mathrm{~m} \times 10 \mathrm{~m})$. A cereal-legume mixture was grown before cultivating spring wheat. The tillage was performed using the ploughing system. The $P$ fertilisers were applied once, prior to wheat sowing: SP and PR were scattered by hand, while SSAB was applied by large-drop sprinkling of the soil. Along with the particular P doses, 1.0, 1.5 and $2.0 \mathrm{~L} / \mathrm{m}^{2} \mathrm{SSAB}$ solutions were applied, respectively.

Nitrogen $(\mathrm{N})$ and potassium $(\mathrm{K})$ fertilisers were applied over the entire experiment area in the following amounts and forms: N, $110 \mathrm{~kg} / \mathrm{ha}$ (ammonium sulphate, 21\% N, 24\% S, Grupa Azoty Puławy, Poland), $\mathrm{K}, 83 \mathrm{~kg}$ (potassium chloride, $60 \% \mathrm{~K}_{2} \mathrm{O}$, Luvena, Luboń, Poland). The entire $\mathrm{K}$ dose was applied before sowing, and the $\mathrm{N}$ dose was divided into two parts: $60 \mathrm{~kg}$ was applied before sowing and $50 \mathrm{~kg}$ at wheat stem elongation.

Wheat was sown on April 9, at a depth of 3-4 cm, with a spacing of $15 \mathrm{~cm}$. Under +PP conditions, wheat was protected: against weeds, with MCPA 300 g/L (3 L/ha, May 19, Chwastox Extra 300 SL, Ciech, Nowa Sarzyna, Poland), against fungal diseases, with azoxystrobin $250 \mathrm{~g} / \mathrm{L}(0.6 \mathrm{~L} / \mathrm{ha}$, June 11, Amistar 250 SC, Syngenta, Warsaw, Poland) and propiconazole $250 \mathrm{~g} / \mathrm{L}+$ cyproconazole $80 \mathrm{~g} / \mathrm{L}(0.4$ L/ha, June 11, Artea 330 EC, Syngenta, Warsaw, Poland), and against insects, with lambda-cyhalothrin $50 \mathrm{~g} / \mathrm{L}$ (0.4 L/ha, June 10, Karate Zeon 050 CS, Syngenta, Warsaw, Poland).

Combine harvesting was performed on August 11.

\subsection{Soil and Meteorological Conditions}

The soil type on the experimental field was Luvisol [38] formed from sandy loam. It contained (total contents) on average: $8.90 \mathrm{~g} / \mathrm{kg} \mathrm{C}, 1.35 \mathrm{~g} / \mathrm{kg} \mathrm{N}, 566 \mathrm{mg} / \mathrm{kg} \mathrm{P}, 2.90 \mathrm{~g} / \mathrm{kg} \mathrm{K}, 2.01 \mathrm{~g} / \mathrm{kg} \mathrm{Mg}$, 0.686 (max $5.795) \mathrm{mg} / \mathrm{kg}$ As, $0.292(\max 0.827) \mathrm{mg} / \mathrm{kg} C d, 19.6(\max 25.0) \mathrm{mg} / \mathrm{kg} \mathrm{Cr}, 8.53(\max 14.78) \mathrm{mg} / \mathrm{kg} \mathrm{Ni}$, and 7.99 (max 25.1) $\mathrm{mg} / \mathrm{kg} \mathrm{Pb}$. The arable layer of soil produced an acid reaction ( $\mathrm{pH}$ in $\mathrm{KCl}$ was 5.32).

The total annual precipitation was $492.3 \mathrm{~mm}$, with $23.4 \mathrm{~mm}, 25.4 \mathrm{~mm}, 43.0 \mathrm{~mm}, 71.0 \mathrm{~mm}$ and 13.0 $\mathrm{mm}$ of the precipitation occurring from April to September, respectively. The mean annual temperature in the research area was $9.1^{\circ} \mathrm{C}$, with the mean monthly temperature ranging from $0.3^{\circ} \mathrm{C}$ in February to $21.3^{\circ} \mathrm{C}$ in September.

\subsection{Sampling and Analyses}

\subsubsection{Soil Moisture and Temperature}

The analysis was conducted three times: at (1) tillering, (2) stem elongation and (3) heading of wheat, by time-domain reflectometry (TDR) with the use of the FOM/mts meter (Field Operated Multimeter for moisture, temperature and salinity; E-Test, sole manufacturer of TDR meters and probes designed by the Institute of Agrophysics of the Polish Academy of Sciences in Lublin, Poland). The measurements were performed in layers of $0-10,10-20$ and $20-30 \mathrm{~cm}$ and repeated five times on each plot.

\subsubsection{Soil $\mathrm{pH}$}

Soil samples were taken from the $0-30 \mathrm{~cm}$ soil layer on three dates: (1) before the start of the experiment, (2) at the wheat leaf development stage, (3) after wheat harvest. The samples were collected using a hand-held twisting probe (Egner's soil sampler) from each plot separately at evenly distributed points. A total of about $1 \mathrm{~kg}$ of soil was gathered from a single plot. The collected soil material was dried at room temperature for several days, then thoroughly mixed and sieved. Afterwards, the 
separated portions of about $300 \mathrm{~g}$ each were passed to the Chemical and Agricultural Station in Olsztyn (Poland), where the $\mathrm{pH}$ in $1 \mathrm{M} \mathrm{KCl}$ was determined by the potentiometric method.

\subsubsection{Content of Elements in Soil}

Soil samples were taken twice: (1) before the start of the experiment and (2) after wheat harvest. Soil collection and preparation for elemental analysis proceeded as described in Section 2.3.2. Samples of soil material of about $300 \mathrm{~g}$ were delivered to the accredited chemical laboratory (number AB 696), where the total content of $\mathrm{C}, \mathrm{N}, \mathrm{P}, \mathrm{K}, \mathrm{Mg}$, $\mathrm{As}, \mathrm{Cd}, \mathrm{Cr}, \mathrm{Ni}$, and $\mathrm{Pb}$ was determined.

The $\mathrm{C}$ and $\mathrm{N}$ contents in soil were determined using the Vario Macro Cube Elementar $(\mathrm{C}, \mathrm{H}, \mathrm{N})$ analyser (Elementar Analysensysteme, Langenselbold, Germany). D-phenylalanine ( $\mathrm{C}=65.44 \%$; $\mathrm{N}=$ $8.48 \%$ ) was used as a standard solution. The contents of other elements were determined using an inductively coupled plasma-optical emission spectrometer (ICP-OES). An appropriate mass ( $0.5 \mathrm{~g})$ of soil samples was digested in Teflon vessels (microwave oven Milestone MLS-1200, Sorisole, Bergamo, Italy) with $10 \mathrm{~mL}$ of aqua regia. After mineralisation, all samples were An ICP-OES with a pneumatic nebuliser with an axial view (iCAP Duo Thermo Scientific, Waltham, MA, USA, diluted to $50 \mathrm{~mL}$ ) was used to determine the concentration of elements in all mineralised and diluted biological samples. Determination of elemental content was carried out with all the principles of measurement traceability. Certificated reference materials were also used to check the quality and metrological traceability. The detection levels of $\mathrm{P}, \mathrm{K}, \mathrm{Mg}$, $\mathrm{As}, \mathrm{Cd}, \mathrm{Cr}, \mathrm{Ni}$, and $\mathrm{Pb}$ in the soil material were 3.59, 2.55, 1.17, 0.5, 0.01, $0.035,0.25$, and $0.15 \mathrm{mg} / \mathrm{kg}$, respectively.

\subsubsection{Abundance of Heterotrophic Bacteria and Fungi}

Soil samples were collected on two dates: at wheat tillering and at full vegetation (wheat heading), as described in Section 2.3.2. The soil samplers were sterilised with $96 \%$ ethanol (Czempur, Piekary Ślaskie, Poland) before switching to a subsequent plot. Immediately after collection, each soil sample was thoroughly mixed, while maintaining sterility. Subsequently, small portions of material from each soil sample were placed in sterile $120 \mathrm{~mL}$ plastic pots, which were forwarded to the microbiological laboratory.

The number of heterotrophic bacteria (colony-forming units, CFUs) was determined on tryptic soy agar (TSA, Merck KGaA, Darmstadt, Germany), containing $15.0 \mathrm{~g} / \mathrm{L}$ tripticase peptone, $5.0 \mathrm{~g} / \mathrm{L}$ papaic digest of soyabean meal, $5.0 \mathrm{~g} / \mathrm{L} \mathrm{NaCl}$, and $15.0 \mathrm{~g} / \mathrm{L}$ agar, and the number of fungi (CFUs) was determined on Rose-Bengal Chloramphenicol (RBC, Merck KGaA, Darmstadt, Germany) agar, containing $5.0 \mathrm{~g} / \mathrm{L}$ mycological peptone, $10.0 \mathrm{~g} / \mathrm{L}$ glucose, $1.0 \mathrm{~g} / \mathrm{L} \mathrm{KH}_{2} \mathrm{PO}_{4}, 0.5 \mathrm{~g} / \mathrm{L} \mathrm{MgSO} 4,0.05 \mathrm{~g} / \mathrm{L}$ rose bengal, $0.1 \mathrm{~g} / \mathrm{L}$ chloramphenicol, and $15.5 \mathrm{~g} / \mathrm{L}$ agar. TSA and RBC media were sterilised in an autoclave at $121^{\circ} \mathrm{C}$ for $20 \mathrm{~min}$. $\mathrm{RBC}$ had a pH of 7.2, and TSA had a pH of 7.3-7.5. The media were cooled to $45-50{ }^{\circ} \mathrm{C}$, thoroughly mixed and poured in the amount of $10 \mathrm{~mL}$ onto Petri plates with soil solution previously deposited on them ( $1 \mathrm{~mL}$ of $10^{-3}, 10^{-4}$ and $10^{-5}$ dilutions). Each dilution was prepared in duplicate. Heterotrophic bacteria were incubated at $30{ }^{\circ} \mathrm{C}$ for $72 \mathrm{~h}$, and fungi were incubated at $28{ }^{\circ} \mathrm{C}$ for 5 days. The emergent colonies of heterotrophic bacteria and fungi were counted and expressed in terms of $1 \mathrm{~g}$ of soil.

\subsubsection{Earthworm (Lumbricidae) Occurrence}

The species composition, number and weight of earthworms (Lumbricidae) in the 0-40 cm soil layer were determined after spring wheat harvest and expressed in terms of $1 \mathrm{~m}^{2}$ of plot area. Earthworms were harvested mechanically: samples of the investigated soil layer were dug out, crushed and passed through a sieve, and individuals of Lumbricidae were collected. Earthworms were anesthetised in a $30 \%$ ethanol (Czempur, Piekary Śląskie, Poland) solution and preserved in a $\%$ formalin (Czempur, Piekary Slaskie, Poland) and 75\% ethanol solution. Their species composition was determined using an identification key to soil-dwelling oligochaetes [39]. 


\subsection{Statistical Analysis}

The results were processed by analysis of variance (ANOVA) or the alternative Kruskal-Wallis test if the analysis of variance assumptions were not met. The normality of variable distribution was checked using the Shapiro-Wilk W-test, and the homogeneity of variance was checked using Levene's test. The differences between objects were evaluated using Duncan's test or a multiple comparison test. In statistical calculations, the soil element contents below the detection level (LD) were replaced by values equal to the LD. For the soil contents of toxic elements, the median and the maximum values were also determined. The calculations were performed using Statistica 12.0 software [40]. Since the interaction between experimental factors was not significant, in the tables only the average values for the main factors are presented.

\section{Results and Discussion}

\subsection{Soil Moisture and Temperature}

These soil features depended mainly on the soil granulometric composition and the hydrological relations of the habitat (surface water and groundwater resources) [41] as well as on the individual dates of analysis and the weather conditions in the periods preceding the measurements.

No differences in soil moisture and temperature caused by the implemented fertiliser variants were proven on any of the methodologically accepted dates or in the tested layers (Table 2).

Table 2. Moisture and temperature of soil with spring wheat.

\begin{tabular}{|c|c|c|c|c|c|c|c|c|c|c|}
\hline \multirow{3}{*}{ Treatments } & & \multicolumn{3}{|c|}{ Wheat Tillering } & \multirow{2}{*}{\multicolumn{3}{|c|}{$\begin{array}{c}\text { Wheat Stem Elongation } \\
\text { Soil Layer Depth, cm }\end{array}$}} & \multicolumn{3}{|c|}{ Wheat Heading } \\
\hline & & \multirow[b]{2}{*}{ 0-10 } & \multirow[b]{2}{*}{$10-20$} & \multirow[b]{2}{*}{$20-30$} & & & & \multirow[b]{2}{*}{ 0-10 } & \multirow[b]{2}{*}{ 10-20 } & \multirow[b]{2}{*}{$20-30$} \\
\hline & & & & & 0-10 & 10-20 & $20-30$ & & & \\
\hline \multicolumn{11}{|c|}{ Moisture (Volumetric Water Content, \%) } \\
\hline \multirow[t]{10}{*}{ P fertilisation } & No P & $11.1 \mathrm{a}$ & $10.6 a$ & $12.0 \mathrm{a}$ & $8.4 \mathrm{a}$ & $5.3 a$ & $4.7 \mathrm{a}$ & $12.1 \mathrm{a}$ & $10.0 \mathrm{a}$ & $7.3 \mathrm{a}$ \\
\hline & $\mathrm{SP}_{1}$ & $11.3 a$ & $10.2 \mathrm{a}$ & $11.2 \mathrm{a}$ & $7.1 \mathrm{a}$ & $4.6 \mathrm{a}$ & $4.6 \mathrm{a}$ & $13.0 \mathrm{a}$ & $9.9 \mathrm{a}$ & $7.1 \mathrm{a}$ \\
\hline & $\mathrm{SP}_{2}$ & $10.7 \mathrm{a}$ & $10.3 a$ & $11.0 \mathrm{a}$ & $7.8 \mathrm{a}$ & $5.4 \mathrm{a}$ & $4.5 \mathrm{a}$ & $11.9 \mathrm{a}$ & $9.1 \mathrm{a}$ & $5.8 \mathrm{a}$ \\
\hline & $\mathrm{SP}_{3}$ & $10.9 \mathrm{a}$ & $12.0 \mathrm{a}$ & $10.8 \mathrm{a}$ & $7.6 a$ & $4.4 \mathrm{a}$ & $4.9 \mathrm{a}$ & $12.0 \mathrm{a}$ & $9.3 \mathrm{a}$ & $7.4 \mathrm{a}$ \\
\hline & $\mathrm{PR}_{1}$ & $10.1 \mathrm{a}$ & $9.6 \mathrm{a}$ & $10.1 \mathrm{a}$ & $7.3 \mathrm{a}$ & $2.8 \mathrm{a}$ & $3.8 \mathrm{a}$ & $12.7 \mathrm{a}$ & $9.8 \mathrm{a}$ & $5.1 \mathrm{a}$ \\
\hline & $\mathrm{PR}_{2}$ & $10.3 a$ & $8.5 a$ & $10.0 \mathrm{a}$ & $8.2 \mathrm{a}$ & $5.5 a$ & $4.8 \mathrm{a}$ & $12.4 \mathrm{a}$ & $9.8 \mathrm{a}$ & $5.2 \mathrm{a}$ \\
\hline & $\mathrm{PR}_{3}$ & $9.9 \mathrm{a}$ & $8.9 a$ & $9.2 \mathrm{a}$ & $8.0 \mathrm{a}$ & $4.1 \mathrm{a}$ & $4.0 \mathrm{a}$ & $12.2 \mathrm{a}$ & $9.5 \mathrm{a}$ & $6.8 \mathrm{a}$ \\
\hline & $\mathrm{SSAB}_{1}$ & $10.7 \mathrm{a}$ & $9.7 \mathrm{a}$ & $10.6 \mathrm{a}$ & $7.5 \mathrm{a}$ & $4.7 \mathrm{a}$ & $5.1 \mathrm{a}$ & $13.1 \mathrm{a}$ & $10.9 \mathrm{a}$ & $7.5 \mathrm{a}$ \\
\hline & $\mathrm{SSAB}_{2}$ & $10.2 \mathrm{a}$ & $10.6 a$ & $11.1 \mathrm{a}$ & $6.7 \mathrm{a}$ & $4.4 \mathrm{a}$ & $5.1 \mathrm{a}$ & $11.2 \mathrm{a}$ & $9.8 \mathrm{a}$ & $7.6 a$ \\
\hline & $\mathrm{SSAB}_{3}$ & $11.0 \mathrm{a}$ & $10.7 \mathrm{a}$ & $11.5 \mathrm{a}$ & $7.3 \mathrm{a}$ & $4.2 \mathrm{a}$ & $3.9 \mathrm{a}$ & $10.8 \mathrm{a}$ & $8.4 \mathrm{a}$ & $5.3 a$ \\
\hline \multirow[t]{2}{*}{ Plant protection } & $-P P$ & 10.0B & $9.5 \mathrm{~B}$ & $10.2 \mathrm{~A}$ & $7.1 \mathrm{~B}$ & $3.7 \mathrm{~B}$ & $4.1 \mathrm{~B}$ & $11.4 \mathrm{~B}$ & $9.1 \mathrm{~B}$ & $6.0 \mathrm{~B}$ \\
\hline & $+\mathrm{PP}$ & $11.2 \mathrm{~A}$ & $10.7 \mathrm{~A}$ & $11.2 \mathrm{~A}$ & $8.1 \mathrm{~A}$ & $5.4 \mathrm{~A}$ & $4.9 \mathrm{~A}$ & $12.9 \mathrm{~A}$ & $10.2 \mathrm{~A}$ & $7.0 \mathrm{~A}$ \\
\hline \multicolumn{11}{|c|}{ Temperature $\left({ }^{\circ} \mathrm{C}\right)$} \\
\hline \multirow[t]{10}{*}{ P fertilisation } & No P & $17.8 \mathrm{a}$ & $18.1 \mathrm{a}$ & $18.1 \mathrm{a}$ & $16.8 \mathrm{a}$ & $16.8 \mathrm{a}$ & $16.8 \mathrm{a}$ & $25.1 \mathrm{a}$ & $24.9 a$ & $24.8 \mathrm{a}$ \\
\hline & $\mathrm{SP}_{1}$ & $17.4 \mathrm{a}$ & $17.2 \mathrm{a}$ & $17.4 \mathrm{a}$ & $16.9 \mathrm{a}$ & $16.9 a$ & $16.9 a$ & $24.3 \mathrm{a}$ & $24.3 a$ & $24.1 \mathrm{a}$ \\
\hline & $\mathrm{SP}_{2}$ & $16.5 a$ & $15.9 \mathrm{a}$ & $16.2 \mathrm{a}$ & $17.1 \mathrm{a}$ & $17.2 \mathrm{a}$ & $17.1 \mathrm{a}$ & $24.4 \mathrm{a}$ & $24.4 \mathrm{a}$ & $24.2 \mathrm{a}$ \\
\hline & $\mathrm{SP}_{3}$ & $16.0 \mathrm{a}$ & $15.9 a$ & $15.9 a$ & $17.0 \mathrm{a}$ & $17.0 \mathrm{a}$ & $17.0 \mathrm{a}$ & $24.4 \mathrm{a}$ & $24.3 a$ & $24.0 \mathrm{a}$ \\
\hline & $\mathrm{PR}_{1}$ & $16.3 a$ & $16.5 a$ & $16.3 a$ & $17.2 \mathrm{a}$ & $17.3 a$ & $17.2 \mathrm{a}$ & $24.0 \mathrm{a}$ & $24.6 \mathrm{a}$ & $24.5 \mathrm{a}$ \\
\hline & $\mathrm{PR}_{2}$ & $16.5 a$ & $16.5 a$ & $16.4 \mathrm{a}$ & $16.9 a$ & 17.1a & $16.9 a$ & $24.6 \mathrm{a}$ & $24.6 a$ & $24.4 \mathrm{a}$ \\
\hline & $\mathrm{PR}_{3}$ & $16.1 \mathrm{a}$ & $16.2 \mathrm{a}$ & $16.1 \mathrm{a}$ & $17.1 \mathrm{a}$ & $17.1 \mathrm{a}$ & $17.1 \mathrm{a}$ & $24.2 \mathrm{a}$ & $25.1 \mathrm{a}$ & $24.9 a$ \\
\hline & $\mathrm{SSAB}_{1}$ & $16.4 \mathrm{a}$ & $16.2 \mathrm{a}$ & $16.4 \mathrm{a}$ & $16.9 \mathrm{a}$ & $17.0 \mathrm{a}$ & $16.9 a$ & $24.6 \mathrm{a}$ & $24.5 a$ & $24.2 \mathrm{a}$ \\
\hline & $\mathrm{SSAB}_{2}$ & $16.7 \mathrm{a}$ & $16.7 \mathrm{a}$ & $16.7 \mathrm{a}$ & $16.7 \mathrm{a}$ & $16.7 \mathrm{a}$ & $16.7 \mathrm{a}$ & $24.1 \mathrm{a}$ & $24.4 \mathrm{a}$ & $24.3 a$ \\
\hline & $\mathrm{SSAB}_{3}$ & $16.1 \mathrm{a}$ & $16.1 \mathrm{a}$ & $16.1 \mathrm{a}$ & $16.8 \mathrm{a}$ & $16.8 \mathrm{a}$ & $16.8 \mathrm{a}$ & $24.7 \mathrm{a}$ & $25.0 \mathrm{a}$ & $24.7 \mathrm{a}$ \\
\hline \multirow{2}{*}{ Plant protection } & $-\mathrm{PP}$ & 16.0B & 16.0B & 16.0B & $17.5 \mathrm{~A}$ & $17.6 \mathrm{~A}$ & $17.5 \mathrm{~A}$ & $25.0 \mathrm{~A}$ & $25.2 \mathrm{~A}$ & $24.9 \mathrm{~A}$ \\
\hline & $+\mathrm{PP}$ & 17.1A & 17.1A & 17.1A & 16.4B & 16.4B & $16.4 \mathrm{~B}$ & $23.9 \mathrm{~B}$ & 24.1B & $23.9 B$ \\
\hline
\end{tabular}

SP: superphosphate, PR: phosphorite, SSAB: SSA with the addition of B. megaterium, - PP: no plant protection, +PP: full chemical plant protection. Different letters within columns indicate significant differences at $p<0.05$ : small letters for P fertilisation treatments, capital letters for plant protection treatments. 
Wheat plants fertilised with SP, PR and SSAB, as well as with no P fertilisation, depleted soil water in the same way and enabled water evaporation. Plant protection contributed significantly to soil moisture and temperature. At tillering, the soil under $+\mathrm{PP}$ showed significantly higher moisture content in 0-10 and 10-20 cm layers than the soil under -PP. For the moisture level at 20-30 cm, only a tendency to increased soil moisture under the influence of $+\mathrm{PP}$ was noted. At the stem elongation and heading stages, at all three levels, the soil under +PP (i.e., weed-free) was characterised by higher moisture. Lower moisture in the -PP soil could be associated with severe weed infestation and greater depletion of soil water by the weeds [42].

At tillering, the soil under +PP showed a higher temperature than the soil under -PP. In turn, at the stem elongation and heading stages, this was reversed: the soil under -PP had a significantly higher temperature than that under +PP. In early spring, weeds probably shaded the soil surface, causing its slower warming [43] and later, by depleting the water from the soil and making it drier, they favoured an increase in soil temperature. Dry soils, as a result of their low thermal conductivity and much smaller heat capacity, tend to warm up easily and have much higher temperatures than moist soils [44]. Moreover, no interaction of fertilisation and plant protection on soil moisture and temperature was found.

\subsection{Soil $\mathrm{pH}$}

The soil in the experiment (Table 3) was characterised by a $\mathrm{pH}<5.5$, which means that the bioavailability of $\mathrm{P}$ in this environment was limited by its incorporation in aluminium (Al) or iron (Fe) compounds [45]. The average soil $\mathrm{pH}$ of 5.32 prior to the experiment significantly decreased at the wheat leaf development stage (to 5.18). This change was related neither to the type and dose of $\mathrm{P}$ fertilisers applied nor to plant protection. Likewise, no interaction of experimental factors was found. After wheat harvest, the $\mathrm{pH}$ averaged 5.20 and did not change statistically in relation to the previous date.

Table 3. $\mathrm{pH}$ of soil with spring wheat (in $1 \mathrm{M} \mathrm{KCl)}$.

\begin{tabular}{cccc}
\hline \multirow{2}{*}{ Treatments } & & $\begin{array}{c}\text { At Wheat Leaf } \\
\text { Development }\end{array}$ & After Wheat Harvest \\
\hline \multirow{2}{*}{ P fertilisation } & $\mathrm{No} \mathrm{P}$ & $5.15 \mathrm{a}$ & $5.19 \mathrm{a}$ \\
& $\mathrm{SP}_{1}$ & $5.25 \mathrm{a}$ & $5.26 \mathrm{a}$ \\
& $\mathrm{SP}_{2}$ & $5.26 \mathrm{a}$ & $5.21 \mathrm{a}$ \\
& $\mathrm{SP}_{3}$ & $5.13 \mathrm{a}$ & $5.15 \mathrm{a}$ \\
& $\mathrm{PR}_{1}$ & $5.11 \mathrm{a}$ & $5.10 \mathrm{a}$ \\
& $\mathrm{PR}_{2}$ & $5.11 \mathrm{a}$ & $5.18 \mathrm{a}$ \\
& $\mathrm{PR}_{3}$ & $5.25 \mathrm{a}$ & $5.31 \mathrm{a}$ \\
& $\mathrm{SSAB}_{1}$ & $5.18 \mathrm{a}$ & $5.21 \mathrm{a}$ \\
& $\mathrm{SSAB}_{2}$ & $5.17 \mathrm{a}$ & $5.16 \mathrm{a}$ \\
& $\mathrm{SSAB}_{3}$ & $5.18 \mathrm{a}$ & $5.18 \mathrm{a}$ \\
\hline Plant protection & $-\mathrm{PP}$ & $5.15 \mathrm{~A}$ & $5.22 \mathrm{~A}$ \\
& $+\mathrm{PP}^{\text {Average }}$ & $5.20 \mathrm{~A}$ & $5.18 \mathrm{~A}$ \\
\hline
\end{tabular}

Different letters within columns indicate significant differences at $p<0.05$ : small letters for P fertilisation treatments, capital letters for plant protection treatments; arrow indicates a significant decrease in relation to the starting state.

Seasonal fluctuations in $\mathrm{pH}$ are not unusual. They are affected by fertiliser rate, time of fertiliser application, organic matter, and root and bacterial activity as well as soil moisture [46]. In our experiment, the spring decrease in $\mathrm{pH}$ could be the result of wheat plants' reaction to the available $P$ deficiency in a situation where $P$ release from the soil pool or from fertilisers was limited by the scarce precipitation at that time. It is known that when P shortage occurs in the phases of high plant demand for $\mathrm{P}$ [47], plants change the soil $\mathrm{pH}$ by releasing organic acids, which increase the solubility of 
P bonded with aluminium ( $\mathrm{Al}$ ), iron (Fe) and manganese (Mn) [32]. In our earlier studies [48], in more beneficial humidity conditions, such an effect was observed (lowering the $\mathrm{pH}$ in relation to the initial state) with no P fertilisation and P application in the form of less soluble compounds (phosphorite, SSA-water solution).

Considering PSM biology [49] and earlier studies by other authors (e.g., [50]), a decrease in soil pH as a result of B. megaterium activity was expected. This effect was not observed, similar to our studies with other fertilisers containing this bacterium [51]. Regardless of the natural buffering capacity of the soil [52], a variation of the soil $\mathrm{pH}$ seems to be related to the abundance of B. megaterium introduced together with the fertiliser, which was relatively too little to influence the total soil PSM population or change the soil pH under field conditions. Although, in laboratory tests, Wyciszkiewicz et al. [53] observed a satisfactory growth rate of B. megaterium when cultured in SSA as a source of phosphorus and this growth was followed by the decrease of medium $\mathrm{pH}$, in field conditions, Jastrzębska et al. [54] found that a fertiliser consisting of SSA and B. megaterium did not increase the abundance of this bacterium in the soil. It is also well known that B. megaterium sporulates quickly in adverse environmental conditions [55], but this process was not investigated in our research.

\subsection{Content of Toxic Elements in the Soil}

The contents of $\mathrm{As}, \mathrm{Cd}, \mathrm{Cr}, \mathrm{Ni}$, and $\mathrm{Pb}$ in the soil in the experiment (Table 4) were within the limits accepted as natural for Polish conditions and did not exceed the permitted levels for arable lands. The average values did not differ from national and regional averages, and even the maximum values were within the geochemical background limits (Table 5). The median values for $\mathrm{As}, \mathrm{Cd}$ and $\mathrm{Pb}$ were below the LD, while for $\mathrm{Cr}$ and $\mathrm{Ni}$ they were lower than the averages.

Table 4. Soil content of toxic elements after spring wheat harvest ( $\mathrm{mg} / \mathrm{kg}$ of soil dry matter).

\begin{tabular}{|c|c|c|c|c|c|c|}
\hline \multicolumn{2}{|c|}{ Treatments } & \multirow{2}{*}{$\begin{array}{c}\text { As } \\
0.64 a\end{array}$} & \multirow{2}{*}{$\frac{\text { Cd }}{0.010 \mathrm{a}}$} & \multirow{2}{*}{$\frac{\mathrm{Cr}}{15.8 \mathrm{a}}$} & \multirow{2}{*}{$\frac{\mathbf{N i}}{7.51 \mathrm{a}}$} & \multirow{2}{*}{$\begin{array}{c}\mathbf{P b} \\
1.13 \mathrm{a}\end{array}$} \\
\hline P fertilisation & No P & & & & & \\
\hline & $\mathrm{SP}_{1}$ & $1.21 \mathrm{a}$ & $0.072 \mathrm{a}$ & $16.2 \mathrm{a}$ & $7.33 a$ & $0.53 a$ \\
\hline & $\mathrm{SP}_{2}$ & $0.50 \mathrm{a}$ & $0.062 \mathrm{a}$ & $16.3 a$ & $7.63 a$ & $2.32 \mathrm{a}$ \\
\hline & $\mathrm{SP}_{3}$ & $2.94 a$ & $0.058 \mathrm{a}$ & $15.8 \mathrm{a}$ & $7.66 a$ & $1.30 \mathrm{a}$ \\
\hline & $\mathrm{PR}_{1}$ & $1.83 \mathrm{a}$ & $0.091 \mathrm{a}$ & $15.2 \mathrm{a}$ & $7.48 \mathrm{a}$ & $1.24 \mathrm{a}$ \\
\hline & $\mathrm{PR}_{2}$ & $1.28 \mathrm{a}$ & $0.151 \mathrm{a}$ & $16.7 \mathrm{a}$ & $7.23 a$ & $1.74 \mathrm{a}$ \\
\hline & $\mathrm{PR}_{3}$ & $0.50 \mathrm{a}$ & $0.010 \mathrm{a}$ & $15.5 a$ & $7.13 a$ & $2.49 a$ \\
\hline & $\mathrm{SSAB}_{1}$ & $1.77 \mathrm{a}$ & $0.066 a$ & $15.2 \mathrm{a}$ & $7.79 \mathrm{a}$ & $2.11 \mathrm{a}$ \\
\hline & $\mathrm{SSAB}_{2}$ & $0.66 a$ & $0.047 \mathrm{a}$ & $15.4 \mathrm{a}$ & $7.62 a$ & $0.50 \mathrm{a}$ \\
\hline & $\mathrm{SSAB}_{3}$ & $0.49 a$ & $0.068 \mathrm{a}$ & $16.0 \mathrm{a}$ & $7.55 a$ & $2.83 a$ \\
\hline \multirow[t]{2}{*}{ Plant protection } & $-\mathrm{PP}$ & $1.13 \mathrm{~A}$ & $0.062 \mathrm{~A}$ & $15.7 \mathrm{~A}$ & $7.60 \mathrm{~A}$ & $1.62 \mathrm{~A}$ \\
\hline & $+\mathrm{PP}$ & $1.23 \mathrm{~A}$ & $0.065 \mathrm{~A}$ & $15.9 \mathrm{~A}$ & $7.39 \mathrm{~A}$ & $1.62 \mathrm{~A}$ \\
\hline Average & & 1.18 & $0.063 \downarrow$ & $15.8 \downarrow$ & $7.49 \downarrow$ & $1.62 \downarrow$ \\
\hline Median & & $<\mathrm{LD}$ & $<\mathrm{LD}$ & 14.8 & 7.34 & $<\mathrm{LD}$ \\
\hline Max & & 8.84 & 0.360 & 21.5 & 14. 8 & 11.9 \\
\hline
\end{tabular}

Different letters within columns indicate significant differences at $p<0.05$ : small letters for P fertilisation treatments, capital letters for plant protection treatments; arrows indicate a significant decrease in relation to the starting state.

Table 5. Reference values for soil content of toxic elements $(\mathrm{mg} / \mathrm{kg})$ according to various sources.

\begin{tabular}{ccccccc}
\hline Content & As & Cd & Cr & Ni & Pb & Reference \\
\hline Geochemical background for Poland & $2-13$ & $0.03-1.00$ & $2.0-64$ & $0.5-28.5$ & $5.0-59.0$ & {$[56,57]$} \\
In surface level of Polish soils & $0.6-35$ & $0.01-1.6$ & $5-100$ & $0.5-60$ & $5-85$ & {$[58]$} \\
Permissible in Poland in arable land & 10 & 2 & 150 & 100 & 100 & {$[59]$} \\
Monitoring of arable soils & -Poland & $0.73-20.7$ & $0.02-68.0$ & $2.4-49.1$ & $1.0-71.1$ & $4.5-857$ \\
& -region & $1.52-3.87$ & $0.07-0.18$ & $4.5-30.6$ & $2.6-29.8$ & $7.6-14.4$ \\
\hline
\end{tabular}

Taking into account the elemental composition of fertilisers (Table 1), the increase in toxic elements' accumulation in the soil was probable, especially in comparison to no P treatment. Assuming that a dry soil from the 0-30 cm-deep layer and 1 ha area weighs $4500 \mathrm{t}$ and replacing the As content in 
SSAB by $0.5 \mathrm{mg} / \mathrm{kg}$ (detection level), 1.11, 1.67 and $2.22 \mu \mathrm{g}$ As, $0.61,0.91$ and $1.22 \mu \mathrm{g} \mathrm{Cd}, 13.20,18.90$ and $26.40 \mu \mathrm{g} \mathrm{Cr}, 5.44,8.17$ and $10.89 \mu \mathrm{g} \mathrm{Ni}$, and 23.11, 34.67 and $46.22 \mu \mathrm{g}$ Pb per $1 \mathrm{~kg}$ of soil were introduced with $\mathrm{SSAB}_{1}, \mathrm{SSAB}_{2}$ and $\mathrm{SSAB}_{3}$, respectively. At the same time, $0.023,0.034$ and $0.045 \mu \mathrm{g}$ As, $0.24,0.35$ and $0.47 \mu \mathrm{g} \mathrm{Cd}$, and $0.19,0.28$, and $0.38 \mu \mathrm{g}$ Pb per $1 \mathrm{~kg}$ of soil were added when $\mathrm{PR}_{1}$, $\mathrm{PR}_{2}$ and $\mathrm{PR}_{3}$, respectively, were applied. However, these amounts of toxic elements were negligible for statistical analysis. No influence of the fertilisation factor on the content of $\mathrm{As}, \mathrm{Cd}, \mathrm{Cr}, \mathrm{Ni}$, and $\mathrm{Pb}$ in the 0-30 cm soil layer was found. SSAB, similarly to SP and PR, regardless of the dose of P, did not significantly change the content of these elements compared to the control (no P). Earlier studies by other authors indicate that feeding plants with fertilisers rich in toxic elements, from primary or secondary resources, may lead to an increase in the content of these elements in soil [61,62], even during one growing season [61]. However, modern technological solutions provide the possibility to reduce the content of toxic elements in fertilisers from ash to a safe level $[7,14,16,17,19]$. The SSAB production method seems to be a good example of such a technology (Table 1). Our other research on SSA-containing fertilisers is also promising [63], although further research is needed, especially long-term studies.

Plant protection (+PP vs $-\mathrm{PP}$ ) also did not differentiate the levels of $\mathrm{As}, \mathrm{Cd}, \mathrm{Cr}, \mathrm{Ni}$ or $\mathrm{Pb}$ in soil, nor was an interaction between fertilisation and plant protection found. The study by Wołejko et al. [64] shows that pesticides may stop or activate the migration of heavy metals from soil to plants. The uptake of elements by plants results in their soil pool depletion. Compared to the initial state (before the start of the experiment), the content of As in soil did not change, and the content of $\mathrm{Cd}, \mathrm{Cr}$, $\mathrm{Ni}$, and $\mathrm{Pb}$ decreased, but this was not related to the application of $\mathrm{P}$ fertilisation or plant protection. The uptake of these elements by plants (wheat and weeds) did not result in a change in their content in plant biomass above levels considered natural [63].

\subsection{Abundance of Heterotrophic Bacteria and Fungi}

The abundance of bacteria and fungi found in the experiment (Table 6) was typical for cropland soils in Poland [65]. In spring (at wheat tillering), the relatively low abundance of bacteria and fungi was probably caused by a shortage of precipitation and, thus, poor soil moisture [66]. Precipitation in July (at wheat heading) probably contributed to an increase in the abundance of these groups of microorganisms.

Table 6. Abundance of heterotrophic bacteria and fungi in the $0-30 \mathrm{~cm}$ layer of soil with spring wheat (CFU $\cdot 10^{5}$ in $1 \mathrm{~g}$ of soil dry matter).

\begin{tabular}{cccccc}
\hline \multirow{2}{*}{ Treatments } & & \multicolumn{2}{c}{ Bacteria } & \multicolumn{2}{c}{ Fungi } \\
\cline { 2 - 6 } & & $\begin{array}{c}\text { Wheat } \\
\text { Tillering }\end{array}$ & $\begin{array}{c}\text { Wheat } \\
\text { Heading }\end{array}$ & $\begin{array}{c}\text { Wheat } \\
\text { Tillering }\end{array}$ & $\begin{array}{c}\text { Wheat } \\
\text { Heading }\end{array}$ \\
\hline \multirow{2}{*}{ P fertilisation } & $\mathrm{No} \mathrm{P}$ & $51.1 \mathrm{a}$ & $73.1 \mathrm{a}$ & $0.76 \mathrm{a}$ & $2.00 \mathrm{a}$ \\
& $\mathrm{SP}_{1}$ & $52.4 \mathrm{a}$ & $81.9 \mathrm{a}$ & $0.47 \mathrm{a}$ & $1.87 \mathrm{a}$ \\
& $\mathrm{SP}_{2}$ & $41.6 \mathrm{a}$ & $94.3 \mathrm{a}$ & $0.78 \mathrm{a}$ & $1.87 \mathrm{a}$ \\
& $\mathrm{SP}_{3}$ & $47.5 \mathrm{a}$ & $70.7 \mathrm{a}$ & $0.91 \mathrm{a}$ & $2.33 \mathrm{a}$ \\
& $\mathrm{PR}_{1}$ & $48.6 \mathrm{a}$ & $78.9 \mathrm{a}$ & $0.55 \mathrm{a}$ & $2.24 \mathrm{a}$ \\
& $\mathrm{PR}_{2}$ & $52.7 \mathrm{a}$ & $62.6 \mathrm{a}$ & $0.72 \mathrm{a}$ & $1.48 \mathrm{a}$ \\
& $\mathrm{PR}_{3}$ & $51.0 \mathrm{a}$ & $69.9 \mathrm{a}$ & $0.74 \mathrm{a}$ & $2.09 \mathrm{a}$ \\
& $\mathrm{SSAB}_{1}$ & $61.3 \mathrm{a}$ & $75.3 \mathrm{a}$ & $0.55 \mathrm{a}$ & $1.54 \mathrm{a}$ \\
& $\mathrm{SSAB}_{2}$ & $57.9 \mathrm{a}$ & $74.1 \mathrm{a}$ & $0.78 \mathrm{a}$ & $2.01 \mathrm{a}$ \\
& $\mathrm{SSAB}_{3}$ & $40.8 \mathrm{a}$ & $71.0 \mathrm{a}$ & $0.72 \mathrm{a}$ & $1.59 \mathrm{a}$ \\
\hline \multirow{6}{*}{ Plant protection } & $-\mathrm{PP}$ & $56.5 \mathrm{~A}$ & $81.5 \mathrm{~A}$ & $0.91 \mathrm{~A}$ & $2.63 \mathrm{~A}$ \\
& $+\mathrm{PP}$ & $44.5 \mathrm{~B}$ & $68.8 \mathrm{~A}$ & $0.49 \mathrm{~B}$ & $1.17 \mathrm{~B}$ \\
\hline
\end{tabular}

Different letters within columns indicate significant differences at $p<0.05$ : small letters for $\mathrm{P}$ fertilisation treatments, capital letters for plant protection treatments. 
The applied fertiliser variants (type of fertiliser and dose) did not affect the abundance of the examined microorganisms on any of the analysis dates. Other studies suggest that the fertiliser type may affect the abundance and structure of soil microflora [34]; however, there are also examples of unchanged microbe amounts even in response to a reduction in the quantity of $\mathrm{P}$ introduced with fertilisers [67].

It appears from the available literature that the introduction of allochthonous microorganisms into the soil may alter the abundance and structure of indigenous microbial communities in different ways $[28,68]$. In our own studies, no influence of B. megaterium introduced into the soil with SSAB on the abundance of soil heterotrophic bacteria and soil fungi was observed. Similar results were obtained in our other studies when B. megaterium was included in a granulated fertiliser produced from SSA and animal bones [51,69]. In a pot experiment, a study noted no negative effect of B. megaterium on soil microbes, when it was used as bioinoculant for seeds of Cajanus cajan [70]. According to Gadhave et al. [28], different species of the genus Bacillus may have distinct effects on microbial communities. The results of our field studies indicated that $B$. megaterium bacteria, introduced into the soil in the amounts required for $S S A B$, do not significantly disturb the ecological structure of soil microbial communities. However, this thesis should be supported by further detailed research.

Plant protection had a negative effect on the abundance of soil bacteria at wheat tillering (spring) and a clear negative tendency on these biota at wheat heading. On both analysis dates, plant protection had a negative effect on the abundance of soil fungi. In the spring time, a significant reduction in the abundance of both groups of microorganisms was probably the effect of herbicides [71], which were applied shortly before soil sampling. At full wheat vegetation, the abundance of bacteria showed a declining tendency, and the abundance of fungi was reduced following a fungicide treatment performed shortly before [72,73]. The reduction in the abundance of soil bacteria and fungi observed in our own studies was probably only short-term. According to Ahtiainen et al. [74], microbial activities and biomass follow the weather conditions during the growing season, and the pesticide treatments show no strong or long-lasting significant effects in field studies. On the other hand, Kalia and Gosal [75] claim that even if the application of pesticide initially decreases microbe number and activity, as the chemical persists, microbes develop tolerance/resistance and re-colonise. In our experiment, the effect of pesticides on B. megaterium introduced with SSAB was not checked (which may be a topic for future research), although Lone et al. [76] reported that PSM did not experience any significant negative effects due to the herbicides.

\subsection{Earthworms (Lumbricidae) Occurrence}

The drought in August (after wheat harvest) did not favour the occurrence of earthworms in the soil plough layer. Under its influence, these organisms probably moved deeper into the soil [77]. On individual plots, in the examined soil column, from zero to several individuals were found (Table S1). Two species were identified, i.e., Allolobophora caliginosa and Allolobophora rosea. The first species was predominant, and the occurrence of the second one was occasional.

The number of earthworms and their weight did not depend on the type of $P$ fertilisers used or their doses. Moreover, no influence of plant protection or interaction of experimental factors on these soil properties was found. In contrast, Iordache and Borza [78] found a negative relationship between earthworm weight and P content in soil. According to later studies, inorganic fertilisers, including superphosphate, can be toxic to earthworms upon direct contact [79,80]. To date, only a few studies have examined the effect of SSA fertilisers on earthworms. In pot research by Khan et al. [81], the influence of fibre industry ash, chemical industry ash, fibre industry sludge and chemical industry sludge on Pheretima posthuma was tested. Four months after the application, they found a decrease in the number of adults, juveniles, cocoons and fresh weight. The authors claimed that the high content of heavy metals in the tested waste was the reason for this phenomenon. Our studies with fertilisers from waste materials, presented here and elsewhere [51,69], carried out in the field, show that fertilisers 
from secondary raw materials with a low content of toxic elements do not pose a threat to soil fauna, if used in reasonable doses.

The harmful effects of pesticides on earthworms have been well documented in the literature [82]. However, there are also reports from field studies demonstrating that pesticides have little effect on earthworms [83] and even show no harmful impact on them if the preparations are used at the recommended doses [84], which also corresponds to our own studies.

\section{Conclusions}

Under field experiment conditions, SSAB did not affect the moisture, temperature or $\mathrm{pH}$ of the soil in the presence of the test plant, did not increase the content of toxic elements in the soil and did not alter the abundance of heterotrophic bacteria, fungi or earthworms in the soil, when applied in reasonable doses. Plant protection had an individual effect on these soil properties but did not modify fertiliser action. The findings argue for using SSAB as a substitute for P fertilisers produced from non-renewable raw materials in times of shortage. However, a full recommendation should be supported by long-term research.

Supplementary Materials: The following are available online at http://www.mdpi.com/2075-163X/9/7/423/s1, Figure S1: Scheme of experimental design, Table S1: Earthworm (Lumbricidae) occurrence in the 0-40 cm layer of soil under spring wheat.

Author Contributions: Conceptualization, M.J. and M.K.K.; methodology, M.J. and M.K.K.; validation, M.J. and M.K.K.; formal analysis, M.J.; investigation, M.J. and M.K.K.; resources, M.J. and M.K.K.; writing-original draft preparation, M.J.; writing_review and editing, M.K.K.; visualization, M.J.; funding acquisition, M.J. and M.K.K.

Funding: This research was funded by National Center for Research and Development, Poland, grant number PBS 2/A1/11/2013.

Acknowledgments: The Institute of New Chemical Synthesis in Puławy is highly acknowledged for providing SSAB and PR for field experiments. Authors kindly acknowledge the technical support of Kinga Treder, Przemysław Makowski and Wiesław P. Jastrzębski from the University of Warmia and Mazury in Olsztyn, and of Agnieszka Saeid and Sylwia Baśladyńska from the Wrocław University of Science and Technology.

Conflicts of Interest: The authors declare no conflict of interest.

\section{References}

1. Heredia, O.S.; Fernández Cirelli, A. Environmental risks of increasing phosphorus addition in relation to soil sorption capacity. Geoderma 2007, 137, 426-431. [CrossRef]

2. Ahemad, M.; Zaidi, A.; Khan, M.S.; Oves, M. Biological importance of phosphorus and phosphate solubilizing microbes-An overview. In Phosphate Solubilizing Microbes for Crop Improvement; Nova: New York, NY, USA, 2009; pp. 1-14.

3. Herrera-Estrella, L.; López-Arredondo, D. Phosphorus: The Underrated Element for Feeding the World. Trends Plant Sci. 2016, 21, 461-463. [CrossRef] [PubMed]

4. Mogollón, J.M.; Beusen, A.H.W.; van Grinsven, H.J.M.; Westhoek, H.; Bouwman, A.F. Future agricultural phosphorus demand according to the shared socioeconomic pathways. Glob. Environ. Chang. 2018, 50, 149-163. [CrossRef]

5. Withers, P.J.A.; van Dijk, K.C.; Neset, T.S.S.; Nesme, T.; Oenema, O.; Rubæk, G.H.; Schoumans, O.F.; Smit, B.; Pellerin, S. Stewardship to tackle global phosphorus inefficiency: The case of Europe. Ambio 2015, 44, 193-206. [CrossRef] [PubMed]

6. Smol, M. The importance of sustainable phosphorus management in the circular economy (CE) model: The Polish case study. J. Mater. Cycles Waste Manag. 2019, 21, 227-238. [CrossRef]

7. Smol, M.; Kulczycka, J.; Kowalski, Z. Sewage sludge ash (SSA) from large and small incineration plants as a potential source of phosphorus-Polish case study. J. Environ. Manag. 2016, 184, 617-628. [CrossRef] [PubMed]

8. Van Kauwenbergh, S.J. World Phosphate Rock Reserves and Resources; IFDC Muscle Shoals: Colbert County, AL, USA, 2010. 
9. Donatello, S.; Cheeseman, C.R. Recycling and recovery routes for incinerated sewage sludge ash (ISSA): A review. Waste Manag. 2013, 33, 2328-2340. [CrossRef] [PubMed]

10. Nesme, T.; Metson, G.S.; Bennett, E.M. Global phosphorus flows through agricultural trade. Glob. Environ. Chang. 2018, 50, 133-141. [CrossRef]

11. Günther, S.; Grunert, M.; Müller, S. Overview of recent advances in phosphorus recovery for fertilizer production. Eng. Life Sci. 2018, 18, 434-439. [CrossRef]

12. Abis, M.; Calmano, W.; Kuchta, K. Innovative technologies for phosphorus recovery from sewage sludge ash. Detritus 2018. [CrossRef]

13. Ottosen, L.M.; Kirkelund, G.M.; Jensen, P.E. Extracting phosphorous from incinerated sewage sludge ash rich in iron or aluminum. Chemosphere 2013, 91, 963-969. [CrossRef] [PubMed]

14. Weigand, H.; Bertau, M.; Hübner, W.; Bohndick, F.; Bruckert, A. RecoPhos: Full-scale fertilizer production from sewage sludge ash. Waste Manag. 2013, 33, 540-544. [CrossRef] [PubMed]

15. Gorazda, K.; Tarko, B.; Wzorek, Z.; Kominko, H.; Nowak, A.K.; Kulczycka, J.; Henclik, A.; Smol, M. Fertilisers production from ashes after sewage sludge combustion-A strategy towards sustainable development. Environ. Res. 2017, 154, 171-180. [CrossRef] [PubMed]

16. Lekfeldt, J.D.S.; Rex, M.; Mercl, F.; Kulhánek, M.; Tlustoš, P.; Magid, J.; de Neergaard, A. Effect of bioeffectors and recycled P-fertiliser products on the growth of spring wheat. Chem. Biol. Technol. Agric. 2016, 3. [CrossRef]

17. Herzel, H.; Krüger, O.; Hermann, L.; Adam, C. Sewage sludge ash-A promising secondary phosphorus source for fertilizer production. Sci. Total Environ. 2016, 542, 1136-1143. [CrossRef] [PubMed]

18. Römer, W.; Steingrobe, B. Fertilizer effect of phosphorus recycling products. Sustainability (Switzerland) 2018, 10, 1166. [CrossRef]

19. Severin, M.; Breuer, J.; Rex, M.; Stemann, J.; Adam, C.; Van den Weghe, H.; Kücke, M. Phosphate fertilizer value of heat treated sewage sludge ash. Plant Soil Environ. 2014, 60, 555-561. [CrossRef]

20. Saeid, A.; Wyciszkiewicz, M.; Jastrzębska, M.; Chojnacka, K.; Gorecki, H. A concept of production of new generation of phosphorus-containing biofertilizers. BioFertP project. Przem. Chem. 2015, 94, 361-365. [CrossRef]

21. El-Komy, H.M.A. Coimmobilization of Azospirillum lipoferum and Bacillus megaterium for successful phosphorus and nitrogen nutrition of wheat plants. Food Technol. Biotechnol. 2005, 43, 19-27.

22. Vary, P.S.; Biedendieck, R.; Fuerch, T.; Meinhardt, F.; Rohde, M.; Deckwer, W.D.; Jahn, D. Bacillus megaterium-from simple soil bacterium to industrial protein production host. Appl. Microbiol. Biotechnol. 2007, 76, 957-967. [CrossRef]

23. Saeid, A.; Prochownik, E.; Dobrowolska-Iwanek, J. Phosphorus solubilization by Bacillus species. Molecules 2018, 23, 2897. [CrossRef] [PubMed]

24. Karpagam, T.; Nagalakshmi, P.K. Isolation and characterization of phosphate solubilizing microbes from agricultural soil. Int. J. Curr. Microbiol. Appl. Sci. 2014, 3, 601-614.

25. Galavi, M.; Yosefi, K.; Ramrodi, M.; Mousavi, S.R. Effect of bio-phosphate and chemical phosphorus fertilizer accompanied with foliar application of micronutrients on yield, quality and phosphorus and zinc concentration of maize. J. Agric. Sci. 2011, 3, 22. [CrossRef]

26. Sundara, B.; Natarajan, V.; Hari, K. Influence of phosphorus solubilizing bacteria on the changes in soil available phosphorus and sugarcane and sugar yields. Field Crop Res. 2002, 77, 43-49. [CrossRef]

27. Syers, J.K.; Johnston, A.E.; Curtin, D. Efficiency of soil and fertilizer phosphorus use. In FAO Fertilizer and Plant Nutrition Bulletin; FAO: Rome, Italy, 2008; Volume 18.

28. Gadhave, K.R.; Devlin, P.F.; Ebertz, A.; Ross, A.; Gange, A.C. Soil Inoculation with Bacillus spp. Modifies Root Endophytic Bacterial Diversity, Evenness, and Community Composition in a Context-Specific Manner. Microb. Ecol. 2018, 76, 741-750. [CrossRef] [PubMed]

29. Jastrzębska, M.; Kostrzewska, M.; Treder, K.; Makowski, P.; Saeid, A.; Jastrzębski, W.; Okorski, A. Fertiliser from sewage sludge ash instead of conventional phosphorus fertilisers? Plant Soil Environ. 2018, 64, 504-511. [CrossRef]

30. Sharma, S.B.; Sayyed, R.Z.; Trivedi, M.H.; Gobi, T.A. Phosphate solubilizing microbes: Sustainable approach for managing phosphorus deficiency in agricultural soils. SpringerPlus 2013, 2. [CrossRef] 
31. McLaughlin, M.J.; McBeath, T.M.; Smernik, R.; Stacey, S.P.; Ajiboye, B.; Guppy, C. The chemical nature of $P$ accumulation in agricultural soils-implications for fertiliser management and design: An Australian perspective. Plant Soil 2011, 349, 69-87. [CrossRef]

32. Balemi, T.; Negisho, K. Management of soil phosphorus and plant adaptation mechanisms to phosphorus stress for sustainable crop production: A review. J. Soil Sci. Plant Nutr. 2012, 12, 547-561. [CrossRef]

33. Latosińska, J. Influence of temperature and time of Sewage sludge incineration on the mobility of heavy metals. Environ. Prot. Eng. 2017, 43, 105-122. [CrossRef]

34. Delcă, E.; Stere, I. Influence of chemical fertilizers and biofertilizers on the dynamics of some microbial groups (heterotrophic bacteria, free nitrogen-fixing bacteria) in Chernozem soil of dobrogea (Cumpăna, valu lui traian). Rom. Agric. Res. 2012, 219-222.

35. Sparling, G.P. Heat output of the soil biomass. Soil Biol. Biochem. 1981, 13, 373-376. [CrossRef]

36. Filipov, F.; Bădeanu, M. Cosideration concerning on the biological neoformation resulting after some Lumbricide activities in greenhouses soils. Res. J. Agric. Sci. 2010, 42, 131-136.

37. Rolewicz, M.; Rusek, P.; Mikos-Szymańska, M.; Cichy, B.; Dawidowicz, M. Obtaining of Suspension Fertilizers from Incinerated Sewage Sludge Ashes (ISSA) by a Method of Solubilization of Phosphorus Compounds by Bacillus megaterium Bacteria. Waste Biomass Valori. 2016, 7, 871-877. [CrossRef]

38. Iuss Working Group WRB. World Reference Base For Soil Resources 2014. International Soil Classification System for Naming Soils and Creating Legends for Soil Maps; Food and Agriculture Organization of the United Nations: Rome, Italy, 2014; update 2015.

39. Kasprzak, K. Soil Oligochaeta. 3. Family: Earthworms (Lumbricidae); Państwowe Wydawnictwo Naukowe: Warsaw, Poland, 1986; p. 186.

40. Statistica (Data Analysis Software System), Version 12; Statistica: Hamburg, Germany, 2014.

41. Baranowski, R.; Pabin, J. Investigations of physical properties of soil in crop rotations with different percentage of cereals. Zesz. Probl. Post. Nauk Rol. 1979, 2018, 207-215.

42. Brant, V.; Pivec, J.; Zábranský, P.; Hakl, J. Water consumption by Asteraceae weeds under field conditions. Weed Biol. Manag. 2012, 12, 71-83. [CrossRef]

43. Yordanova, M.; Nikolov, A. Influence of Plant Density and Mulching on Growth and Yield of Lettuce (Lactuca sativa var. romana L.). Fields Interests 2017, 3, 5. [CrossRef]

44. Wojkowski, J.; Skowera, B. Związek temperatury gleby z temperatura powietrza w warunkach jurajskiej doliny rzecznej. Ecol. Eng. 2017, 18. [CrossRef]

45. Sapek, B. Soil phosphorus accumulation and release-sources, processes, causes. Water Environ. Rural Areas 2014, 14, 45 .

46. Murdock, L.; Call, D. Managing Seasonal Fluctuations of Soil Tests; AGR-189; University of Kentucky Cooperative Extension: Lexington, Kentucky, 2006; pp. 1-3.

47. Rouached, H.; Arpat, A.B.; Poirier, Y. Regulation of phosphate starvation responses in plants: Signaling players and cross-talks. Mol. Plant 2010, 3, 288-299. [CrossRef]

48. Jastrzębska, M.; Kostrzewska, M.; Treder, K.; Jastrzębski, W.; Makowski, P. Phosphorus biofertilizers from ash and bones-Agronomic evaluation of functional properties. J. Agric. Sci. 2016, 8, 58-70. [CrossRef]

49. Mohammadi, G.R.; Ghobadi, M.E.; Sheikheh-Poor, S. Phosphate biofertilizer, row spacing and plant density effects on corn (Zea mays L.) yield and weed growth. Am. J. Plant Sci. 2012, 3, 425. [CrossRef]

50. Rosyadi, I. Studies on the Agricultural Utilization of Phosphate from Incinerated Sewage Sludge and Meat E Bone Meal; Cuvillier Verlag: Göttingen, Germany, 2004.

51. Jastrzębska, M.; Kostrzewska, M.K.; Makowski, P.; Treder, K.; Jastrzębski, W.P. Granulated phosphorus fertilizer made of ash from biomass combustion and bones with addition of Bacillus megaterium in the field assessment. Part 3. Impact on selected properties of soil environment of winter wheat. Przem. Chem. 2017, 96, 2180-2183. [CrossRef]

52. Václavková, Š.; Šyc, M.; Moško, J.; Pohořelý, M.; Svoboda, K. Fertilizer and Soil Solubility of Secondary P Sources-The Estimation of Their Applicability to Agricultural Soils. Environ. Sci. Technol. 2018, 52, 9810-9817. [CrossRef] [PubMed]

53. Wyciszkiewicz, M.; Saeid, A.; Dobrowolska-Iwanek, J.; Chojnacka, K. Utilization of microorganisms in the solubilization of low-quality phosphorus raw material. Ecol. Eng. 2016, 89, 109-113. [CrossRef] 
54. Jastrzębska, M.; Kostrzewska, M.K.; Makowski, P.; Treder, K.; Marks, M. Effects of ash and bone phosphorus biofertilizers on bacillus megaterium counts and select biological and physical soil properties. Pol. J. Environ. Stud. 2015, 24, 1603-1609. [CrossRef]

55. Gomathy, M.; Thangaraju, M.; Gunasekaran, S.; Gopal, N.O. Sporulation and regeneration efficiency of phosphobacteria (Bacillus megaterium var phosphaticum). Ind. J. Microbiol. 2007, 47, 259-262. [CrossRef] [PubMed]

56. Kucharczak-Moryl, E.; Moryl, A.; Żmuda, R. Influence of the environment on the content of arsenic in cultivated soils in Zgorzelec-Bogatynia region. Ecol. Eng. 2014, 2014, 107-116.

57. Czarnowska, K. Total content of heavy metals in parent rocks as reference background levels of soils. Rocz. Glebozn. 1996, 47, 43-50.

58. Kabata-Pendias, A.; Pendias, H. Biogeochemistry of Trace Elements; Polish Scientific Publishing Company: Warsaw, Poland, 1999; p. 400.

59. ME-PL. Ordinance by the Minister of the Environment (Poland) of 1 September 2016 on assessment procedures for the land surface pollution. J. Laws Repub. Poland 2016, 2016, 1395.

60. IUNG. The Monitoring of the Chemistry of the Polish Arable Soils; Institute of Soil Science and Plant Cultivation (IUNG): Puławy, Poland, 2017.

61. Atafar, Z.; Mesdaghinia, A.; Nouri, J.; Homaee, M.; Yunesian, M.; Ahmadimoghaddam, M.; Mahvi, A.H. Effect of fertilizer application on soil heavy metal concentration. Environ. Monit. Assess. 2010, 160, 83-89. [CrossRef] [PubMed]

62. Belhaj, D.; Elloumi, N.; Jerbi, B.; Zouari, M.; Abdallah, F.B.; Ayadi, H.; Kallel, M. Effects of sewage sludge fertilizer on heavy metal accumulation and consequent responses of sunflower (Helianthus annuus). Environ. Sci. Pollut. Res. 2016, 23, 20168-20177. [CrossRef] [PubMed]

63. Jastrzębska, M.; Saeid, A.; Kostrzewska, M.K.; Basladyńska, S. New phosphorus biofertilizers from renewable raw materials in the aspect of cadmium and lead contents in soil and plants: P-biofertilizers from waste and $\mathrm{Cd}$ and $\mathrm{Pb}$ in soil and plant. Open Chem. 2018, 16, 35-49. [CrossRef]

64. Wołejko, E.; Łozowicka, B.; Kaczyński, P.; Konecki, R.; Grobela, M. The influence of chemical protection on the content of heavy metals in wheat (Triticum aestivum L.) growing on the soil enriched with granular sludge. Environ. Monit. Assess. 2017, 189. [CrossRef] [PubMed]

65. Wolinska, A. Dehydrogenase activity of soil microorganism and oxygen availability during reoxidation process of selected mineral soils from Poland. In Acta Agrophysica. Rozprawy i Monografie; Polska Akademia Nauk: Lublin, Poland, 2010.

66. Natywa, M.; Selwet, M.; Maciejewski, T. Effect of some agrotechnical factors on the number and activity soil microorganisms. Fragm. Agron. 2014, 31, 56-63.

67. Guan, G.; Tu, S.; Li, H.; Yang, J.; Zhang, J.; Wen, S.; Yang, L. Phosphorus fertilization modes affect crop yield, nutrient uptake, and soil biological properties in the rice-wheat cropping system. Soil Sci. Soc. Am. J. 2013, 77, 166-172. [CrossRef]

68. Felici, C.; Vettori, L.; Giraldi, E.; Forino, L.M.C.; Toffanin, A.; Tagliasacchi, A.M.; Nuti, M. Single and co-inoculation of Bacillus subtilis and Azospirillum brasilense on Lycopersicon esculentum: Effects on plant growth and rhizosphere microbial community. Appl. Soil Ecol. 2008, 40, 260-270. [CrossRef]

69. Jastrzębska, M.; Kostrzewska, M.K.; Makowski, P.; Treder, K.; Jastrzębski, W.P. Functional properties of granulated ash and bone-based phosphorus biofertilizers in the field assessment. Part 3. Impact on selected properties of soil environment of winter wheat. Przem. Chem. 2016, 95, 1591-1594. [CrossRef]

70. Gupta, R.; Mathimaran, N.; Wiemken, A.; Boller, T.; Bisaria, V.S.; Sharma, S. Non-target effects of bioinoculants on rhizospheric microbial communities of Cajanus cajan. Appl. Soil Ecol. 2014, 76, 26-33. [CrossRef]

71. Tejada, M.; García-Martínez, A.M.; Gómez, I.; Parrado, J. Application of MCPA herbicide on soils amended with biostimulants: Short-time effects on soil biological properties. Chemosphere 2010, 80, 1088-1094. [CrossRef]

72. Wang, F.; Li, X.; Zhu, L.; Du, Z.; Zhang, C.; Wang, J.; Lv, D. Responses of soil microorganisms and enzymatic activities to azoxystrobin in cambisol. Pol. J. Environ. Stud. 2018, 27, 2775-2784. [CrossRef]

73. Osman, A.G.; Va, E.; Bikov, K.V. Effect of New Broad Spectrum Fungicide Amistar on Soil Microorganisms in Field Conditions. J. Sci. Technol. 2005, 6, 207-213.

74. Ahtiainen, J.H.; Vanhala, P.; Myllymäki, A. Effects of different plant protection programs on soil microbes. Ecotoxicol. Environ. Saf. 2003, 54, 56-64. [CrossRef] 
75. Kalia, A.; Gosal, S.K. Effect of pesticide application on soil microorganisms. Arch. Agron. Soil Sci. 2011, 57, 569-596. [CrossRef]

76. Lone, A.H.; Raverkar, K.P.; Pareek, N. In-vitro effects of herbicides on soil microbial communities. Bioscan 2014, 9, 11-16.

77. Edwards, C.A.; Bohlen, P.J. Biology and Ecology of Earthworms, 3rd ed.; Chapman \& Hall: London, UK, 1996; p. 426.

78. Iordache, M.; Borza, I. Relation between chemical indices of soil and earthworm abundance under chemical fertilization. Plant Soil Environ. 2010, 56, 401-407. [CrossRef]

79. Abbiramy, K.S.K.; Ross, P.R.; Paramanandham, J.P. Assessment of acute toxicity of superphosphate to Eisenia foetida using paper contact method. Asian J. Plant Sci. Res. 2013, 3, 112-115.

80. Shruthi, N.; Biradar, A.P.; Muzammil, S. Toxic effect of inorganic fertilizers to earthworms (Eudrilus eugeniae). J. Entomol. Zool. Stud. 2017, 5, 1135-1137.

81. Khan, M.U.; Ahmed, M.; Nazim, K. The population behavior of earth worm (Oheritema posthuma Kinberg) under the influence of industrial waste. FUUAST J. Biol. 2017, 7, 1-8.

82. Pelosi, C.; Barot, S.; Capowiez, Y.; Hedde, M.; Vandenbulcke, F. Pesticides and earthworms. A review. Agron. Sustain. Dev. 2014, 34, 199-228. [CrossRef]

83. Frimpong, J.O.; Ofori, E.S.K.; Yeboah, S.; Marri, D.; Offei, B.K.; Apaatah, F.; Sintim, J.O.; Ofori-Ayeh, E.; Osae, M. Evaluating the impact of synthetic herbicides on soil dwelling macrobes and the physical state of soil in an agro-ecosystem. Ecotoxicol. Environ. Saf. 2018, 156, 205-215. [CrossRef] [PubMed]

84. Iglesias, J.; Castillejo, J.; Castro, R. The effects of repeated applications of the molluscicide metaldehyde and the biocontrol nematode Phasmarhabditis hermaphrodita on molluscs, earthworms, nematodes, acarids and collembolans: A two-year study in north-west Spain. Pest Manag. Sci. 2003, 59, 1217-1224. [CrossRef] [PubMed]

(C) 2019 by the authors. Licensee MDPI, Basel, Switzerland. This article is an open access article distributed under the terms and conditions of the Creative Commons Attribution (CC BY) license (http://creativecommons.org/licenses/by/4.0/). 